\title{
Transformational Leadership for School Productivity in Vocational Education
}

\author{
A. Komariah \\ Universitas Pendidikan Indonesia \\ aan_komariah@upi.edu
}

\begin{abstract}
The problem arouse in Vocational School graduates shown that the schools need to enhance its productivity. School productivity becomes the principal's responsibility by adapting the transformational leadership style. This research aimed at describing and analyzing the impact of the transformational leadership on school productivity. This present study used correlation research method to 286 Vocational School teachers in Bandung Regency. The research finding indicates that there is a positive and significant impact of transformational leadership on the school productivity.
\end{abstract}

Keywords - Transformational Leadership, School Productivity, Vocational School

\section{INTRODUCTION}

Productivity at vocational school is a part of very attractive educational administration study. It is not only because at vocational school, it is known the productive learning, but it also relates to the big cost spent compared to the graduation quality enabling to be absorb by the work world. This big cost relates to the cost required for the learning with higher practical proportion than the theory. The practical learning at vocational school requires many and expensive tools as well as special cost for not few field practices. However, the school selection at vocational school with bigger cost has benefits than the students have to drop out and become total unemployment. Hoxby said that, Although productivity is rarely mentioned and productivity calculations are never made, however, it is very influential on student performance compared to calculate the cost of risk in school. An improvement in the education productivity is needed related from the last problem. (Hoxby, 2003)

The Problems from the low productivity cannot be tolerated or allowed to drag on because it concerns all the education purpose, which is reflected from the output from the education as stated by Mulyasa. (2011:92) That productivity throughout the education world is related with the whole regulation process and the use of resources to fulfill the education purpose effectively and efficiently. It relates to this, it is necessary for the educational productivity improvement and increase. An improvement in the education productivity is needed related from the last problem. The effort to increase the productivity is conducted at some countries by giving voucher program trusted to be able to help the school to improve its productivity. (McMillan, 2005).

Some of the studies showed that productivity will be experiencing an increase when it is supported with an appropriate style of leadership and the skills that are optimal as well as a great work motivation. In addition, there has to pursue improvement on some factors to realize the productivity. Rois (2008:10) shows the factor which is lowering the productivity, namely: 1) The Headmaster performances that aren't followed by an unclear structure of vision and mission; 2) School organization culture that isn't conducive yet; and 3) the unoptimal teacher competence, as well as lack of facilities and infrastructure in school.

Rois's studies emphasize, that the school productivity will be increasing when it's paying attention on the increasing school capacity on some of the factors like leadership, organization culture, and the teacher performance. Saparudin (2012:18) concludes the studies results that the Headmaster's performance, school culture, teacher competence and the need of school facilities contribute as significantly towards the school productivity. Likewise, with the study results from Rahmat (2012:272) which concludes that the Headmaster leadership, school funding, school culture, and the teacher's teaching performance simultaneously effected significantly towards the academic service quality.

A viewpoint that pushes the needs for school to have a leadership that orientated towards productivity was given by Tracy and Hinkin (Gill and co, 2010). They stated that the focus on productivity leadership is leadership and assumptions that affect the attitude of members of the organization in building organizational commitment. Such leadership called transformational leadership (TFL). TFL as a form of leadership intended to motivate and inspire followers to pursue higher-order goals through the transformation of followers' attitudes, beliefs, values, and behaviors (To, Tse, \& Ashkanasy, 2015).

Study results from Gentillucci \& Muto (2007:232) shows that Headmaster's leadership behavior to execute his role as the instructional leader have a significant impact on the creation of effective school and student achievements. Some of the other studies are done to prove the presence of direct and indirect transformational leadership towards the student achievements 
(Leithwood, Day, Sammons, Harros, \& Hopkins, 2006; Leithwood, Seashore Louis, Anderson, \& Wahlstrom, 2004). Headmaster's leadership quality is a key to improve and develop the organization learning. Although leadership explains only about three to five percent of the variation in student learning across schools, this effect is actually nearly one- quarter of the total effect of all school factors. (Stewart, 2006).

The transformational leadership is not a new concept, at least, Bryman (1992) has said when he stated new study in 1992. But in Indonesia, the study on transformational leadership is relatively new. The previous study results state that the transformational leadership approach is very fundamental to reach the leadership goals wanting to support the capacity development led at higher level. By the transformational leadership, the individual and organizational capacity are increasing and growing the commitment to reach the bigger school productivity ( Burns, 1978; Bass , 1985). Kenneth Leithwood Doris Jantzi, (2000). Not only as the new approach, is the transformational leadership also the universal phenomena among the complexity of leader's and follower's roles in increasing the school productivity. The transformational leaders focus on restructuring the school by improving school conditions. (Stewart, 2006).

Bass (1998) explains 4 dimensions of Transformational leadership, namely: Charismatic Leadership or Idealized Influence, Inspirational Motivation, Intellectual Stimulation and Individualized Consideration. (Stewart, 2006). While, the study conducted by Leithwood and Steinbach (1995) has put the transformational aspect on six dimensions, namely: building school vision and goals; providing intellectual stimulation; offering individualized support; symbolizing professional practices and values; demonstrating high performance expectations; and developing structures to foster participation in school. Leithwood, 1994; Leithwood et al., 1999; Kenneth Leithwood Doris Jantzi, 2000). While Kouzes \& Posner, (2007) shows the five components of leader behaviour, namely challenging the process, inspiring a shared vision, enabling others to act, modelling the way, and encouraging the heart. (Dunn, Dastoor, \& Sims, 2012).

Related from the statement above then this studies asked what is the effect of the transformational leadership toward the Vocational High School productivity in Bandung Regency. In general, this studies aim to find out how big is the effect from the transformational leadership towards the Vocational High School productivity in Bandung Regency.

The scope of these studies is limited on the two variables, namely school productivity and the transformational leadership. According to the theoretical basis, the variable of the forming factors for each variable studies are the following: 1) The Variable of the transformational leadership (X1) formed through 4 variable factors: a) idealized influence b) inspirational motivation c) intellectual stimulation, and d) individualized consideration. The variable of school productivity (Y2), formed through 3 variable factors: a) administrative, b) economical, and c) psychological.

This study expresses the facts on the transformational leadership and productivity at vocational school, so that it is very appropriate to the survey method. The correlation analysis is a data processing technique used in this study based on the goals to know the extent of the variations in one or more other factors based on the correlation coefficient. This study is conducted at Vocational High School in Bandung Regency with the study targets are the teachers as the population. This study is conducted at 286 people, by the sample selection is by proportional random sampling at productive teachers and minimally has worked for 5 years. This study uses primary data collected by survey with the questionnaires as the study instruments.

The measurement uses the Multifactor Leadership Questionnaire (MLQ) adapted from Avolio, et al (2004), Bass (1998), (Ghafoor, Qureshi, Khan, \& Hijazi, 2011), (Stewart, 2006) and the school productivity criteria from Alan Thomas (Komariah, 2014) with the statement is as the behaviour scale at undesired situation. The answer alternative used in the instrument selected is by five alternatives, namely ranging from very agree, agree, sometimes, less agree, and very disagree. The instrument used previously has been through the calibration process and instrument trial.

The data analysis is conducted to know the relationship between the $\mathrm{X} 1$ variable as the independent variable and variable $\mathrm{Y}$ as the dependent variable, by the correlation coefficient calculation. The determination coefficient analysis is a analysis to know the contribution of independent variable effect on the dependent variable in percentage. The high and low of relationship level between the study variables can be seen from the amount of correlation coefficient value (r) obtained from the study data analysis results by using SPPSS 16.0 software. To know the functional relationship between the independent variable and dependent variable is conducted the regression analysis symbolized by $Y=f(X)$, which the average change of $\mathrm{Y}$ value is set by the decrease and increase of each $\mathrm{X}$ unit value.

\section{THE EFFECT OF THE TRANSFORMATIONAL LEADERSHIP TO THE PRODUCTIVE SCHOOL}

Transformational leadership has a positive and significant effect on productive school. Temuan pertama ini sejalan dengan teori Transformational Leadership with Factors

The 4 "I"s dari Bass dkk yang menjelaskan bahwa The 4 "I"s ini dapat menstimulasi bawahan/pengikut untuk bergerak menjalankan misinya masing-masing secara produktif dengan cara pemimpin transformasional mengartikulasikan visi masa depan organisasi yang realistik, menstimulasi bawahan dengan cara yang intelektual, dan menaruh parhatian pada perbedaanperbedaan yang dimiliki oleh bawahannya. The first conclusion is parallel with the theory of Transformational Leadership with Factors. The 4 "I"s from Bass and co. which described or explained that These 4 "I"s can stimulate followers to move running each mission as productively with how the transformational leaders articulate the organization's vision of the future realisticly, stimulate followers with a intellectual way, and place an attention on the differences which owned by their followers. The four factors are very interesting and important to be implemented on to the headmaster leadership 
to realize the school mission as a learning organization which is in inside there are many efforts to transforms their behavior.

The first "I" is to idealized influence charisma, that is explained as a behaviour which generates respect and trust from the person who lead them. An example from these first "I" is a headmaster who makes the teacher and his employee respect, believe, and trusted him. A charismatic leader can be recognized from his behavior which shows understanding and maintaining the vision and mission of the organization, has a strong stance or establishment, committed, and always consistent towards each decision that already been taken.

The second $\mathrm{T}$ is the inspirational motivation, reflected in the behaviour which always provides challanges for the staff or the employee and showing as well the meaning of their jobs for the staff or the employee. A leader shows or demonstrates commitment for the organization through a behavior that are observed by the staff. A leader is a motivator that always trying to raise the enthusiasm and optimism of the staff. In this second dimention, the transformational leader is described as a leader that can articulate hopes clearly to his followers, demonstrate his commitment to all of the organization goals, and wake the team spirit in the organization with enthusiasm and optimism.. In other words, a transformational leader is giving always inspiration and motivation to his followers.

The third "I" is intellectual stimulation, namely a leader that actualize inovations. Attitude and behaviour of the leadership is based on his devoloping knowledge and as intellectually he can translate it on his productive performance. A leader often explores a new idea and solution to approach and enlighten his staff. As discussed by Bass and Avolio (1994) intellectual stimulation is the enhancement of the followers ability to think own his own related to his work tasks. Intellectual stimulation is defined as the ability of an individual to be logical, rational and able to intelligently adopt from certain situations (Dionne et al., 2003). (Ghafoor et al., 2011). On this third dimension the transformational leader have to create and generate new ideas, giving a creative solution towards the problems that his followers faced, and giving a motivation for that his followers can seek a new approach to do their works in the organization. In other words, the transformational leader can stimulate his followers to be creative and innovative to do their tasks.

The fourth "I" is the individualized consideration. A leader reflected himself as a person who has an affection on responding and following up the staff's problems, ideas, hopes, and other feedbacks. On this last stage, the transformational leader is described as a leader who wants to give his affection towards his followers and specifically wants to care the followers need on his career development. Individualized consideration as the consideration of employee's individuality. Transformational leaders link priorities of every follower's with the development of the organization (Bass and Avolio, 1994). Leaders focus on the development and training of employees that create promotion opportunities Avolio et al., 2004). The outcomes of these characteristics depend on the ability of the leader to stimulate and direct followers in order to achieve desired outcomes (Bass, 1994; Bass and Avolio, 1994; Avolio et al., 2004. (Ghafoor et al., 2011). In other words, the transformational leader can notice and appreciate followers on their needs in achievement, career development, and their performance.

It is very clear that the position of a leader brings a strategic role on empowering the teachers to perform professionally. This statement isin line with the theory Good Strategic Leader from Hill and Jones (2009) which described that there are 5 main keys to guide the leader's followers, namely yaitu (1) Vision, eloquence and consistency; (2) Articulation of a business model; (3) Commitment; (4) Being well informed; (5) Willingness to delegate and empower; (6) Astute use of power; and Emotional intelligence.To be a good leader, headmaster needs to have and implement some leading skill on:, (1) solid on motivating the teachers (motivating power); (2) having an empathy that can be seen and felt from the followers (empathy); (3) showing often his whole personality from his words and action (integrity), and (4) being a creator to find solution to solve problems (intuitive ability). (Lunenburg and Ornstein (2004).

The study findings about leadership and performance indicates that the leader needs to realize his leadership authentically because of his strategic role to guide the behavior of his followers to reach the organization vision together. The institutional failure in maintaining the progress or even the decline of an organization, often makes the leader as the first person taking the responsibility, "When goals are not met, people lose confidence in, and tend to blame those people believed to be responsible for leadership". (Stewart, 2006). So, it is necessary for the leader to improve the self capacity in the leadership by trying to be authentic.

This contain authentically means to the followers that they can really feel the presence of their leaders. It is in line with the theory of Authentic Leadership from Bill George (2003:76) the theory explains that authentic leadership is a type of leadership that prioritize self-awareness on other dimension, which on the reality have to notice the 5 authentic leader dimensions, namely purpose, values, hear, relationships, and self-discipline. Avolio, Gardner \& Walumbwa (2005:243) stated 4 other dimension namely self awareness, Transparency, Ethical/Moral, and Balanced Processing.

Avolio et al. (2004:56) defined the authentic leader as a leader which is very aware how they think and behave and be considered from the other person as a leader who has moral strength, confidence, full of hopes, optimistic, tough, as well as a high moral characteristic. With the following characteristics a leader should build 4CS that makes his value shown to be a role models,Komariah says(2006:29).This 4CS is an identity of a leaderwhich is built on Casing, Comunicating, Competencies, Contributing, and Sample.

Bernard Bernard Bass (Gill et al, 2010:65) interpreted the transformational leadership as the "leadership and performance beyond expectations", which place quality always on the top from service including the service towards the teacher performance implementation on an effort to create academic climate which enhance the value of learning organization in school. A transformative headmastes is a headmaster who has a leadership quality that often to attempt transform the value on himself an his follower to be united to the reach the 
organization vision and mission through a emphatic relation and a climate creation which is delightful so that mutual trust can be created.This statement refers to Komariah's opinion (2004:77) that through a transformational leadership various initiative is expected to appear in the followers which can generate various policy, knowledge, even a developing skills.

\section{CONCLUSION}

There is a positive and significant transformational leadership towards school productivity. The productivity can be measured from the change of the student's behavior as a result of learning process to meet the needs of the student according to the characteristic and the task of the students as well as improving the student's potential overall. School is a learning place which give a quality learning service through a various learning strategy, continuous valuation with a quick and exact follow-up, participate the students into the learning as well as observing the student's presence, implement the student tasks and the sustainability of their tasks.

\section{REFERENCES}

[1] Avolio, B., Gardner, W., Walumbwa, F., \& May, D. (2004). Unlocking the mask: A look at the process by which authentic leaders impact follower attitudes and behaviors. Leadership Quarterly, 15(6), 801-823.

[2] Bass, B. (1998). Transformational leadership: Industry, military, and educational impact. Mahwah, NJ: Erlbaum Associates.

[3] Dunn, M. W., Dastoor, B., \& Sims, R. L. (2012). Transformational Leadership and Organizational Commitment: A Cross-Cultural Perspective. Journal of Multidisciplinary Research, 4, 45-60.

[4] Gill, A., Fitzgerald, S., Bhutani, S., Mand, H., and Sharma, S. 2010. The Relationship Between Transformational Leadership and Employee Desire for Empowerment. International Journal of Contemporary Hospitality Management, Vol. 22 No. 2: P 263-273.

[5] Gentilucci, J.L., \& Muto, C.C. 2007. Principals' Influence on Academic Achievement: The Student Perspective. The National Association of Secondary School Principals. Education Journal. P.232

[6] George, Bill. (2003) .Authentic Leadership; Rediscovering the Secrets to Creating Lasting Value.San Fransisco: Jossey-Bass

[7] Ghafoor, A., Qureshi, T. M., Khan, M. A., \& Hijazi, S. T. (2011). Transformational leadership, employee engagement and performance: Mediating effect of psychological ownership. African Journal of Business Management, 5, 7391-7403. Retrieved from <Go to ISI $>: / / 000296234600027$

[8] Hill Jones. 2012. Journal of Strategic Leadership, Vol. 4 Iss. 1, 2012, pp. $01-08$

[9] Hoxby, C. M. (2003). School choice and school productivity: Could school choice be a tide that lifts all boats? The Economics of School Choice.

[10] Komariah, Aan. dan Triatna, Cepi. 2004. Visionary Leadership Menuju Sekolah Efektif. Jakarta: Bumi Aksara.

[11] Komariah, Aan. 2014. The Impact Of Transformational Leadership, School Climate, And Teacher's-Teaching Performance On School Productivity. Mimbar Pendidikan Unisba

[12] Kouzes, J. M., \& Posner, B. Z. (1997). Leadership practices inventory: Participant's workbook. San Francisco: Jossey-Bass.

[13] Kenneth Leithwood Doris Jantzi, (2000),"The effects of transformational leadership on organizational conditions and student engagement with school", Journal of Educational Administration, Vol. 38 Iss 2 pp. $112-129$

[14] Leithwood, K. (1994), "Leadership for school restructuring", Educational Administration Quarterly, Vol. 30 No. 4, pp. 498-518.
[15] Leithwood, K., Jantzi, D. \& Hopkins, C.M. 2006. The Development and Testing of a School Improvement Model. School Effectiveness and School Improvement, 17 (4): 441-464.

[16] Leithwood, K. and Jantzi, D. (1999), “Principal and teacher leadership effects: a replication", submitted to School Leadership and Management. Leithwood, K. and Steinbach, R. (1995), Expert Problem Solving, State University of New York Press, Albany, NY.

[17] Leithwood, K., Jantzi, D. and Steinbach, R. (1999), Changing Leadership for Changing Times, Open University Press, London.

[18] Lunenburg, F.C., \& Ornstein, A.C. 2004. Educational administration: Concepts and practices (3rd ed.). Belmont, CA: Wadsworth Thomson Learning

[19] McMillan, R. (2005). Erratum to "Competition, incentives, and public school productivity" [J. Public Econ. 88 (9-10) (2004) 1871-1892]. Journal of Public Economics, 89(5-6), 1131. http://doi.org/10.1016/j.jpubeco.2004.09.001

[20] Mulyasa, 2011. Manajemen dan Kepemimpinan Kepala Sekolah. Jakarta: Bumi Aksara.Owens, R. G. 1991.Organizational Behavior in Education. New Jersey: Prentice-Hall, Inc

[21] Rahmat, Endang. 2012. Mutu Layanan Akademik Sekolah Menengah Atas.Disertasi tidak diterbitkan. Bandung: Sekolah Pascasarjana UPI

[22] Rois, M. 2008. Pengaruh Gaya Kinerja Kepala MA terhadap Kompetensi Guru dalam Peningkatan Mutu Pendidikan. Tidak Diterbitkan. Program Pasca Sarjana: UIN SGD Bandung.

[23] Saparudin, Yudhi. 2012. Pengembangan Produktivitas Madrasah. Jurnal Administrasi Pendidikan. Vol XIII No 2 2012: 16-25

[24] Stewart, J. (2006). Instructional and transformational leadership: Burns, Bass and Leithwoood. Canadian Journal of Educational Administration and Policy, 54, 1-29.

[25] To, M. L., Tse, H. H. M., \& Ashkanasy, N. M. (2015). A multilevel model of transformational leadership, affect, and creative process behavior in work teams. The Leadership Quarterly. http://doi.org/10.1016/j.leaqua.2015.05.005 